\title{
A FUNÇÃO SOCIAL DA PROPRIEDADE E A PROGRESSIVIDADE EXTRAFISCAL DO IPTU
}

\author{
LA FUNCIÓN SOCIAL DE LA PROPIEDAD Y LA PROGRESIVIDAD EXTRAFISCAL \\ DEL IPTU
}

${ }^{1}$ Andréa Cristina Correia de Souza Renault Baêta dos Santos

\begin{abstract}
RESUMO
O presente trabalho visa analisar a função social da propriedade e a progressividade extrafiscal do IPTU. Para tanto é imprescindível fazer um estudo acerca dos aspectos relevantes do referido imposto, como fato gerador, base de cálculo, sujeitos ativo e passivo e alíquotas. Posteriormente será explorada a evolução histórica do direito de propriedade o que possibilitará a compreensão da função social da propriedade urbana. Tal instituto possui grande relevância no ordenamento jurídico brasileiro, pois demonstra que a proteção ao direito de propriedade é uma garantia desde que a mesma esteja atrelada à sua função social. Ao final serão feitos apontamentos sobre a extrafiscalidade do IPTU, onde se concluirá que esta função é eficaz instrumento de política urbana para propiciar um melhor aproveitamento do solo e combate à concentração de terras com finalidade eminentemente especulativa. A metodologia a ser utilizada no estudo do tema será observacional exploratória, com análise do objeto desta pesquisa por meio da coleta de doutrina além da análise histórica do instituto da função social da propriedade.
\end{abstract}

Palavras-chave: Função social, Propriedade, Progressividade, IPTU

\begin{abstract}
El presente trabajo pretende analizar la función social de la propiedad y la progresividad extrafiscal del IPTU. Para esto es esencial hacer un estudio sobre los aspectos importantes del referido impuesto, como hecho imponible, base de cálculo, sujetos activo y pasivo y tasas. Después será explorada la evolución histórica del derecho de la propiedad lo que va a posibilitar la comprensión de la función social de la propiedad urbana. Este instituto tiene grande relevancia en el ordenamiento jurídico brasileño porque demuestra que la protección del derecho de la propiedad es una garantía desde que la misma esté junto de su función social. Al final serán hechos apuntamientos sobre la extrafiscalidad del IPTU, donde se va a concluir que en esta función es eficaz instrumento de política urbana para propiciar un mejor aprovechamiento del suelo y la lucha a la concentración de tierras con finalidad sólo especulativa. La metodología que se utilizará en el estudio va a ser de observación, con análisis del objeto de la pesquisa por la búsqueda de doctrina y examen histórico del instituto de la función social de la propiedad.
\end{abstract}

Keywords: Función social, Propiedad, Progresividad, IPTU

\footnotetext{
${ }^{1}$ Mestre em Direito Empresarial e Professora da Pós Graduação (Especialização em Direito Notarial e Registral) na Faculdade Milton Campos, Belo Horizonte - Minas Gerais - MG, (Brasil). E-mail: andreabaetasantos@gmail.com
} 


\section{INTRODUÇÃO}

Em análise às receitas tributárias brasileiras percebe-se que a arrecadação em relação aos impostos incidentes sobre o patrimônio possui baixa representatividade, sendo considerada uma das causas para tanto, a ausência de política fiscal e de planejamento tributário.

O fator fundamental para a alteração neste quadro atual é o estudo da função social da propriedade, que gerará consequências diretas, tanto no imposto territorial rural - ITR como no predial e territorial urbano - IPTU. Entretanto, sua primordial incumbência é a consecução de finalidades constitucionalmente previstas de respeito à fauna e flora, exploração racional da propriedade e atendimento às necessidades coletivas, sendo a mudança na arrecadação, uma consequência.

Assim, o presente artigo tem por finalidade o estudo da função social da propriedade urbana e dos instrumentos previstos pela Constituição Federal e pelo Estatuto da Cidade para sua consecução, sendo imprescindível para tanto a análise dos aspectos relevantes do IPTU e da extrafiscalidade.

\section{ASPECTOS RELEVANTES DO IPTU}

O imposto sobre a propriedade predial e territorial urbana - IPTU é de competência dos Municípios conforme artigo 156, I da Constituição Federal de $1988^{1}$, entretanto, o poder para sua instituição já coube aos Estados, conforme estipulado em constituições anteriores.

Seu fato gerador, de acordo com o estabelecido no artigo 32 da Lei 5.172 de 25 de outubro de 1996 - Código Tributário Nacional é a propriedade, o domínio útil ou a posse de bem imóvel por natureza ou acessão física que esteja localizado na zona urbana do município $^{2}$. A partir de uma interpretação sistemática, tais institutos são mais bem compreendidos com o auxílio da lei civil, conforme adiante explicitado.

\footnotetext{
1 Disponível em: <http://www.planalto.gov.br/ccivil_03/constituicao/constituicaocompilado.htm> Acesso em: 15 jan. 2015. Art. 156. Compete aos Municípios instituir impostos sobre: I - propriedade predial e territorial urbana;

2 Disponível em: <http://www.planalto.gov.br/ccivil_03/leis/15172.htm> Acesso em: 09 fev. 2015.
} 
A propriedade é o mais completo direito real, seu titular concentra todos os poderes inerentes ao domínio pleno: usar, gozar, dispor e reaver ou reivindicar. Segundo Peluso (2014, p. 1114) “o CC/2002, abraçou o conceito de propriedade como relação jurídica complexa, carregada de direitos e deveres e voltada à vocação primordial de atender à função social”3.

É também fato gerador do imposto o domínio útil, desta forma, é importante abordar brevemente o instituto da enfiteuse, também chamada de emprazamento ou aforamento. Constitui um direito real "que confere a alguém, perpetuamente, poderes inerentes ao domínio, com a obrigação de pagar ao dono da coisa uma renda anual, conhecida como foro" (FARIAS, ROSENVALD, 2006, p. 560). O titular do domínio sobre o imóvel é chamado senhorio e é ele quem percebe o foro; já o enfiteuta, foreiro ou titular do domínio útil é aquele que possui o bem de forma imediata, sendo o contribuinte do tributo.

O Código Civil de 2002 filiou-se à teoria objetiva defendida por Ihering, para conceituar a posse, como sendo o direito exercido por aquele que tem de forma plena ou não, algum dos poderes inerentes ao proprietário.

Por fim, bem imóvel por natureza ou acessão física é o solo e os bens, que a ele estão presos de forma natural ou artificial e não podem ser transportados sem alteração em sua substância. Cumpre elucidar que o IPTU incide sobre as benfeitorias, contrariamente ao imposto territorial rural - ITR, que é também classificado como um imposto sobre o patrimônio e possui como base de cálculo o valor fundiário do imóvel, ou seja, o preço da terra nua.

Verifica-se que o legislador infraconstitucional "expandiu" o conceito, abrangendo o domínio útil e a posse, situações não previstas pelo constituinte, que definiu como fato gerador apenas a propriedade; quanto a este tema, temos os ensinamentos de Coêlho (2010, p. 329), para quem,

O intuito do legislador da lei complementar tributária foi o mesmo do legislador latino: atingir o proprietário do bem imóvel ou o "quase-proprietário" (o enfiteuta), ou ainda o que aparentava ser "o proprietário" (o possuidor). O legislador tributário é, deve ser sempre, pragmático. ${ }^{5}$

\footnotetext{
Art. 32. O imposto, de competência dos Municípios, sobre a propriedade predial e territorial urbana tem como fato gerador a propriedade, o domínio útil ou a posse de bem imóvel por natureza ou por acessão física, como definido na lei civil, localizado na zona urbana do Município.

3 PELUSO, Cesar (Coord.). Código Civil Comentado. 8. ed. rev. e ampl. São Paulo: Manole, 2014, p. 1.114.

4 FARIAS, Cristiano Chaves de; ROSENVALD, Nelson. Direitos Reais. 2. ed. Rio de Janeiro: Lúmen Juris Editora, 2006, p. 560.

5 COÊLHO, Sacha Calmon Navarro. Curso de Direito Tributário Brasileiro. 11. ed. Rio de Janeiro: Forense, 2010 , p. 329.
} 
O citado autor complementa seu raciocínio, de forma esclarecedora:

\begin{abstract}
Não que tenha inovado a Constituição, criando por sua conta um imposto sobre a posse e o domínio útil. Não é qualquer posse que deseja ver tributada. [...] A posse prevista no Código Tributário Nacional, como tributável, é a da pessoa que já é ou pode vir a ser proprietária da coisa. [...] E só quando a posse exterioriza a propriedade é possível tomá-la como núcleo do fato jurígeno criador da obrigação tributária do IPTU (COÊLHO, 2010, p. 329) ${ }^{6}$.
\end{abstract}

Assim, são tributáveis por meio do IPTU, além da propriedade, também a posse e o domínio útil. Constitui ainda elemento componente do fato gerador do imposto, o critério espacial, segundo o qual, referido tributo incide naqueles imóveis que, por natureza ou acessão física, estejam localizados na zona urbana do município. Percebe-se neste particular que o CTN utilizou o regramento considerando a localização e não a destinação do bem. A definição de zona urbana cabe ao município que deverá se orientar pela existência de no mínimo dois melhoramentos, a seguir descritos, construídos ou mantidos pelo Poder Público:

- meio-fio ou calçamento, com canalização de águas pluviais;

- abastecimento de água;

- sistema de esgotos sanitários;

- rede de iluminação pública, com ou sem posteamento para distribuição domiciliar; e,

- escola primária ou posto de saúde a uma distância máxima de 3 (três) quilômetros do imóvel considerado ${ }^{7}$.

A base de cálculo do imposto é o valor venal do imóvel, apurado pela municipalidade conforme cadastro feito pela administração tributária e constitui-se do preço que o bem alcançaria em condições normais de mercado se fosse colocado a venda à vista, "sem incluir qualquer encargo relativo a financiamento"8 (MACHADO, 2006, p. 402). Importante destacar que não estão abrangidos no cálculo do tributo, segundo estipulado pelo CTN, os bens móveis que são mantidos de forma permanente ou temporária no imóvel, para finalidade de exploração, utilização, aformoseamento e comodidade ${ }^{9}$.

\footnotetext{
6 COÊLHO, Sacha Calmon Navarro. Curso de Direito Tributário Brasileiro. 11. ed. Rio de Janeiro: Forense, 2010 , p. 329.

7 Disponível em: <http://www.planalto.gov.br/ccivil_03/leis/15172.htm> Acesso em: 09 fev. 2015. Art. 32, $\$ 1^{\circ}$.

8 MACHADO, Hugo de Brito. Curso de Direito Tributário. 27. ed. rev. atual. e ampl. São Paulo: Malheiros Editores, 2006, p. 402.

9 Disponível em: <http://www.planalto.gov.br/ccivil_03/leis/15172.htm> Acesso em: 09 fev. 2015. Art. 33. A base do cálculo do imposto é o valor venal do imóvel.
} 
O sujeito ativo é o Município onde se situa o imóvel. O lançamento do tributo é efetuado de ofício pelas Prefeituras e os contribuintes são apenas notificados para o seu pagamento.

O sujeito passivo do imposto é o proprietário, possuidor e o titular do domínio útil, no caso de enfiteuse. Por expressa disposição legal contida no artigo 1.371 do Código Civil, o superficiário também é responsável pelo pagamento do tributo em comento ${ }^{10}$.

Considerando a diversidade de situações que podem ocorrer na prática em relação ao contribuinte, os tribunais são recorrentemente chamados a se manifestar, sem solução pacífica até o momento para algumas questões, mas a doutrina tem apontado uma alternativa para por fim ao dissídio. Na hipótese de usufruto, como permanecem os direitos do nu-proprietário, será ele o contribuinte do imposto, pois detém o domínio. Na promessa de compra e venda o sujeito passivo da obrigação tributária será o proprietário, e não o promitente comprador; entretanto, se a mesma for irrevogável, irretratável e inscrita no Registro Imobiliário competente, terá o promitente comprador um direito real intangível sobre a coisa e desta forma, poderá legitimamente ser elencado como contribuinte. Ademais, é preciso atentar para o nome constante do lançamento municipal nestas situações especiais.

Em relação a este particular, sintetiza Machado:

\begin{abstract}
Entendemos que o contribuinte do imposto sobre a propriedade predial e territorial urbana é o proprietário, se este reúne em seu patrimônio os dois domínios do imóvel. Se há enfiteuse, o contribuinte é o titular do domínio útil. E, finalmente, se alguém, com animo de proprietário, tem a posse do imóvel, faltando-lhe para ser proprietário apenas o titulo respectivo, então será esse titular da posse o contribuinte. (2006, p.

$403)^{11}$.
\end{abstract}

As alíquotas serão fixadas livremente pelo Município sem qualquer parâmetro estabelecido pela Constituição Federal ou pelo CTN. O Supremo Tribunal Federal - STF, já se manifestou acerca da progressividade de alíquotas, considerando-a constitucional, entretanto, posteriormente modificou este entendimento.

\footnotetext{
Parágrafo único. Na determinação da base de cálculo, não se considera o valor dos bens móveis mantidos, em caráter permanente ou temporário, no imóvel, para efeito de sua utilização, exploração, aformoseamento ou comodidade.

10 Disponível em: <http://www.planalto.gov.br/ccivil_03/leis/15172.htm> Acesso em: 09 fev. 2015.

Art. 34. Contribuinte do imposto é o proprietário do imóvel, o titular do seu domínio útil, ou o seu possuidor a qualquer título. Disponível em: <http://www.planalto.gov.br/ccivil_03/leis/2002/110406.htm> Acesso em: 09 fev. 2015. Art. 1.371. O superficiário responderá pelos encargos e tributos que incidirem sobre o imóvel.

11 MACHADO, Hugo de Brito. Curso de Direito Tributário. 27. ed. rev. atual. e ampl. São Paulo: Malheiros Editores, 2006, p. 403.
} 
Com a promulgação da Constituição em 1988, discutiu-se novamente o tema, pois no artigo $156, \mathrm{I}, \S 1^{\circ}$ houve a previsão da progressividade de alíquotas, além da hipótese prevista no artigo $182, \S 4^{\circ}$, II, que trata, no capítulo destinado à política urbana, do descumprimento da função social da propriedade.

O STF acolheu a inconstitucionalidade da progressividade do IPTU, considerando ser o mesmo um tributo real que não deve ser permeado pela capacidade contributiva, aplicável aos impostos pessoais. Contudo, em 13 de setembro de 2000, foi publicada a Emenda Constitucional n. 29, que possibilitou a progressividade no tempo em razão do valor do imóvel e alíquotas diferenciadas em conformidade com a sua localização e uso.

Por fim, a súmula 668 do STF estabeleceu serem inconstitucionais as leis municipais que antes da Emenda Constitucional n. 29, citada acima, tinham estabelecido alíquotas progressivas em relação ao IPTU, exceto se a finalidade fosse a de assegurar a função social da propriedade $^{12}$.

Quanto às alíquotas, a progressividade está assentada, conforme ensinamentos de Coêlho (2010, p. 333) em dois pilares: “A) a matriz da politica urbana, [...] em prol da ordenação urbanística das municipalidades (progressividade extrafiscal no tempo); e B) a matriz da capacidade do contribuinte que exsurge do art. $145, \S 1^{\circ}$, da CF”,13.

E complementa:

Então há uma progressividade fiscal (art. $145, \S 1^{\circ}$ ) e outra extrafiscal (art. 182, $\S 4^{\circ}$ ). Ademais, as alíquotas poderão ser diferenciadas em razão do uso (industrial, residencial, para fins filantrópicos etc.) e da localização (áreas nobres, áreas de risco etc.). (COÊLHO, 2010, p. 333). ${ }^{14}$

Desta forma, destaca-se que a progressividade fiscal é a graduação do imposto de forma a compatibilizá-lo com o princípio da capacidade contributiva, já a progressividade extrafiscal, que será posteriormente estudada de forma pormenorizada, objetiva influenciar a atuação do contribuinte em direção a determinada meta constitucionalmente prevista.

\footnotetext{
12 Disponível em:

<http://www.stf.jus.br/portal/cms/verTexto.asp?servico=jurisprudenciaSumula\&pagina=sumula_601_700> Acesso em: 09 fev. 2015.

13 COÊLHO, Sacha Calmon Navarro. Curso de Direito Tributário Brasileiro. 11. ed. Rio de Janeiro: Forense,2010, p. 333.

14 COÊLHO, Sacha Calmon Navarro. Curso de Direito Tributário Brasileiro. 11. ed. Rio de Janeiro: Forense, 2010 , p. 333.
} 


\section{EVOLUÇÃO HISTÓRICA DO DIREITO DE PROPRIEDADE}

A noção de propriedade veio evoluindo com o decorrer dos tempos, sendo consequência direta da organização política. Por assim dizer, a propriedade começou com um caráter comunitário no início das civilizações.

Dentro do direito romano a propriedade passou por uma evolução, passando a ter, em última análise, um sentido individualista.

Na Idade Média a propriedade surgiu como um usufruto condicional concedido pelo Estado a certas pessoas, em troca de serviços prestados, passando, posteriormente, a ser perpétua e transmissível pela linha masculina ${ }^{15}$.

A Igreja Católica influenciou muito a noção de propriedade, tendo em vista sua doutrina social. Para São Tomás de Aquino ${ }^{16}$ a propriedade tem fundamento na lei natural na medida em que não é contrária a esta lei. Todavia, a propriedade não foi instituída pela lei natural, mas foi positivada, foi instituída pela lei humana. Neste sentido, "cabe ao legislador equilibrar uma distribuição eqüitativa da mesma entre os indivíduos, de modo a evitar grandes disparidades sociais, atribuindo, prudentemente, a cada um o seu” (BITTAR, 2000, p. 148) ${ }^{17}$. Ainda existe a preocupação de São Tomás de Aquino com a propriedade como sendo um direito fundado na lei natural, considerando-se um antecedente do princípio da função social da propriedade.

Dentro da Declaração dos Direitos do Homem e do Cidadão de 1789, concebida após a Revolução Francesa, que por sua vez foi liderada pela burguesia que se via preterida em razão do poder monárquico, feudal, a propriedade foi garantida de forma absoluta, irrestrita e de uso ilimitado. Esta noção de propriedade fez surgir um anseio da burguesia àquela época.

No início da colonização do Brasil a propriedade recebeu a feição feudal através das Capitanias Hereditárias. Posteriormente, já a partir da Constituição Federal de 1824, seguiu-se à concepção romana de propriedade: individualista.

\footnotetext{
15 DINIZ, Maria Helena. Curso de Direito Civil Brasileiro: Direito das Coisas. 17ed. São Paulo: Saraiva, 2002.

16 Pela filosofia tomista a lei é a concretização do direito, que por sua vez é o objeto da justiça. Deste modo, existem várias categorias de lei: a lei eterna, promulgada por Deus, que tudo ordena; a lei natural, que é uma lei comum a homens e animais, sendo a lei da natureza; lei comum a todas as gentes, que é uma lei extraída da lei natural e só se aplica aos homens; e a lei humana, que é convencional e relativa. Todavia, todas as leis devem estar de acordo com a lei eterna, sendo certo que a lei natural é a expressão racional da lei eterna. Neste sentido Bittar (2000, p. 132134).

17 BITTAR FILHO, Carlos Alberto. A apropriação do solo no Brasil colonial e monárquico: uma perspectiva histórico-jurídica. Revista de informação legislativa: v. 37, n. 148. out./dez. 2000, p. 148.
} 
A Constituição Federal de 1824 garantia a propriedade de modo irrestrito e absoluto, só permitindo a desapropriação em caráter excepcional, com prévia indenização, conforme artigo 179 e seu inciso XXII ${ }^{18}$. Tal fato se repete em relação a Constituição de 1891.

A Constituição Federal de 1934 introduziu a ideia de função social da propriedade. Esta noção se repetiu nas Cartas Constitucionais seguintes: 1937, 1946, 1967 e também na atual, de 1988.

O Código Civil de 1916 trouxe uma concepção exclusivista e ilimitada do direito de propriedade onde se conferia ao proprietário as faculdades de uso, gozo e disponibilidade dos bens, conforme se depreende dos artigos $524^{19}$ e $527^{20}$.

Todavia, esta concepção individualista e absoluta da propriedade nunca chegou a contrariar frontalmente o direito de propriedade resguardado na Constituição Federal, visto que, conforme esclarece José Afonso da Silva:

o Direito Civil não disciplina a propriedade, mas tão-somente regula as relações civis a ela pertinentes. Assim, só valem no âmbito das relações civis as disposições do Código Civil que estabelecem as faculdades de usar, gozar e dispor de bens (art.

524), a plenitude da propriedade (art. 525), o caráter exclusivo e ilimitado do domínio (art. 527) etc. ${ }^{21}$ (SILVA, 2000, p. 69-70).

Ainda assim, dentro do Direito Civil este conceito absoluto de propriedade foi evoluindo e, no Brasil, atualmente, o Código Civil de 2002 está em sintonia com a Constituição de 1988, que por sua vez chegou ao ápice da evolução com a função social que deve estar impressa na noção de propriedade.

\footnotetext{
18 Disponível em: <http://www.planalto.gov.br/ccivil_03/Constituicao/Constituicao24.htm>. Acesso em: 09 fev.2015.

Art. 179. A inviolabilidade dos Direitos Civis, e Politicos dos Cidadãos Brazileiros, que tem por base a liberdade, a segurança individual, e a propriedade, é garantida pela Constituição do Imperio, pela maneira seguinte. [...] XXII. E'garantido o Direito de Propriedade em toda a sua plenitude. Se o bem publico legalmente verificado exigir o uso, e emprego da Propriedade do Cidadão, será elle préviamente indemnisado do valor della. A Lei marcará os casos, em que terá logar esta unica excepção, e dará as regras para se determinar a indemnisação.

Disponível em: <http://www.planalto.gov.br/ccivil_03/Constituicao/Constituicao24.htm>. Acesso em: 09 fev.2015.

Art. 524. A lei assegura ao proprietário o direito de usar, gozar e dispor de seus bens, e de reave-los do poder de quem quer que injustamente os possua.

20 Disponível em: < http://www.planalto.gov.br/ccivil_03/leis/L3071.htm>. Acesso em: 09 fev. 2015. Art. 527. O domínio presume-se exclusivo e ilimitado, até prova em contrário.

${ }^{21}$ SILVA, José Afonso da. Direito Urbanístico Brasileiro. 3.ed. São Paulo: Malheiros, 2000, p. 69-70
} 


\section{A FUNÇÃO SOCIAL DA PROPRIEDADE URBANA}

No século XIX, na França, ocorreram dois casos paradigmáticos que são considerados marcos para o estudo da função social da propriedade: a) o proprietário de um imóvel construiu uma chaminé com o objetivo de expelir gases nos terrenos vizinhos e, b) o proprietário edificou, para causar danos a um dirigível que partia do imóvel confinante, um muro que continha hastes de ferro. Em ambos, ficou definido pela corte que o direito de propriedade não pode ser utilizado, mesmo que por seu titular, com o propósito exclusivo de prejudicar, ou causar danos a terceiros, sem produzir qualquer proveito.

Tais casos são considerados protótipos, pois eles representam as primeiras restrições estabelecidas ao direito de propriedade que, até então, era considerado absoluto.

Com a evolução do capitalismo houve grande preocupação com a intensificação do lucro, acumulação de riquezas e apropriação de bens, sem, contudo, deixar espaço para o exame das questões relacionadas à coletividade. Este cenário gerou incertezas e "os valores da liberdade individual e da igualdade formal não poderiam prosperar em cenários de extenso desequilíbrio econômico" (FARIAS, ROSENVALD, 2006, p. 199) ${ }^{22}$.

Como consequência de tal conjuntura, ao ser editada a Constituição Federal de 1988, preocupou-se em dar destaque a situações extrapatrimoniais, assim, “o individuo solitário, isolado em sua atividade econômica, é convertido na pessoa solidária que convive em sociedade e encontra nas necessidades do outro um claro limite à sua liberdade de atuação" (FARIAS, ROSENVALD, 2006, p. 199) ${ }^{23}$.

A função social da propriedade remonta à necessidade de cumprimento de um papel ou atividade e se traduz em uma atuação positiva por parte do proprietário, que deve se comportar de forma a viabilizar a realização de benefícios sociais sem se olvidar do seu interesse particular.

Como visto, a Constituição Federal de 1988 não garante simplesmente o direito de propriedade de forma absoluta e ilimitada. Logo após garantir o direito de propriedade, determina-se, de modo prescritivo, que a propriedade deverá atender a sua função social. Daí decorre que a garantia constitucional à propriedade como direito individual do cidadão existe desde que a propriedade esteja a atender a sua função social.

22 FARIAS, Cristiano Chaves de; ROSENVALD, Nelson. Direitos Reais. 2. ed. Rio de Janeiro: Lúmen Juris Editora, 2006 , p. 199.

23 FARIAS, Cristiano Chaves de; ROSENVALD, Nelson. Direitos Reais. 2. ed. Rio de Janeiro: Lúmen Juris Editora, 2006, p. 199. 
Ao dispor acerca da Ordem Econômica e Financeira, que tem por escopo maior realizar os objetivos fundamentais da República, elencados no artigo $3^{\circ}$ da Magna Carta, o legislador constituinte deixou expresso no artigo $170^{24}$, a relação entre propriedade privada e sua função social, vejamos:

Artigo 170. A ordem econômica, fundada na valorização do trabalho humano e na livre iniciativa, tem por fim assegurar a todos existência digna, conforme os ditames da justiça social, observados os seguintes princípios: [...]

II - propriedade privada;

III - função social da propriedade;

Conforme exposto, a propriedade privada existe dentro da ordem econômica para resguardar a todos uma existência digna, de modo a se alcançar os objetivos da República, mas ainda assim, não é a propriedade numa visão absolutista que vai servir a esse fim, mas a propriedade que atenda a sua função social.

É assim também nos artigos da Constituição Federal $182^{25}$ que trata da Política Urbana, 185, Parágrafo Único ${ }^{26}$ e $186^{27}$ que dispõem sobre Política Agrícola e Fundiária e da Reforma Agrária, que atrelam a propriedade à sua função social.

\footnotetext{
24 Disponível em: <http://www.planalto.gov.br/ccivil_03/constituicao/constituicaocompilado.htm> Acesso em: 15 jan. 2015.

25 Disponível em: <http://www.planalto.gov.br/ccivil_03/constituicao/constituicaocompilado.htm> Acesso em:15 jan. 2015.
}

Art. 182. A política de desenvolvimento urbano, executada pelo Poder Público municipal, conforme diretrizes gerais fixadas em lei, tem por objetivo ordenar o pleno desenvolvimento das funções sociais da cidade e garantir o bem- estar de seus habitantes.

$\S 1^{\circ} \mathrm{O}$ plano diretor, aprovado pela Câmara Municipal, obrigatório para cidades com mais de vinte mil habitantes, é o instrumento básico da política de desenvolvimento e de expansão urbana.

$\S 2^{\circ}$ A propriedade urbana cumpre sua função social quando atende às exigências fundamentais de ordenação da cidade expressas no plano diretor. $\S 3^{\circ}$ As desapropriações de imóveis urbanos serão feitas com prévia e justa indenização em dinheiro.

$\S 4^{\circ}$ É facultado ao Poder Público municipal, mediante lei específica para área incluída no plano diretor, exigir, nos termos da lei federal, do proprietário do solo urbano não edificado, subutilizado ou não utilizado, que promova seu adequado aproveitamento, sob pena, sucessivamente, de: I - parcelamento ou edificação compulsórios;

II - imposto sobre a propriedade predial e territorial urbana progressivo no tempo;

III - desapropriação com pagamento mediante títulos da dívida pública de emissão previamente aprovada pelo Senado Federal, com prazo de resgate de até dez anos, em parcelas anuais, iguais e sucessivas, assegurados o valor real da indenização e os juros legais.

26

26 Disponível em: <http://www.planalto.gov.br/ccivil_03/constituicao/constituicaocompilado.htm> Acesso em: 15 jan. 2015.

Art. 185. São insuscetíveis de desapropriação para fins de reforma agrária: [...] Parágrafo único. A lei garantirá tratamento especial à propriedade produtiva e fixará normas para o cumprimento dos requisitos relativos a sua função social.

27 Disponível em: <http://www.planalto.gov.br/ccivil_03/constituicao/constituicaocompilado.htm> Acesso em:15 jan. 2015.

Art. 186. A função social é cumprida quando a propriedade rural atende, simultaneamente, segundo critérios e graus de exigência estabelecidos em lei, aos seguintes requisitos:

I - aproveitamento racional e adequado;

II - utilização adequada dos recursos naturais disponíveis e preservação do meio ambiente; III - observância das disposições que regulam aselações e trabalho;

IV - exploração que favoreça o bem-estar dos proprietários e dos trabalhadores. 
Portanto, em linhas gerais, a propriedade está "socializada", mas não no sentido dado à propriedade pelos socialistas, de que a propriedade deve ser repartida entre todos, mas no sentido de que ela só tem legitimidade se estiver atendendo a sua função social. Em conformidade com a lição de Carvalho (2004, p. 407), "a função social da propriedade, que corresponde a uma concepção ativa e comissiva do uso da propriedade, faz com que o titular do direito seja obrigado a fazer, a valer-se de seus poderes e faculdades, no sentido do bem comum" 28 .

Farias e Rosenvald (2006, p. 201) também conceituam a função social da propriedade e segundo eles, ela é "um princípio que opera um corte vertical em todo o sistema de direito privado. Ela se insere na própria estrutura de qualquer direito subjetivo para justificar a razão pela qual ele serve e qual papel desempenha".

Importante destacar a diferença entre função social da propriedade, que se traduz em uma obrigação de fazer e limitações ao direito de propriedade, que regra geral, consubstanciam obrigações de não fazer, com normas oriundas do direito de vizinhança e administrativo.

A legislação infraconstitucional também dá ênfase à função social da propriedade a colocando como uma cláusula geral, que recebe destaque no Código Civil de 2002, junto aos poderes inerentes ao proprietário, vejamos:

\begin{abstract}
Artigo 1.228. O proprietário tem a faculdade de usar, gozar e dispor da coisa, e o direito de reavê-la do poder de quem quer que injustamente a possua ou detenha. $\S 1^{\circ}$ : O direito de propriedade deve ser exercido em consonância com as suas finalidades econômicas e sociais e de modo que sejam preservados, de conformidade com o estabelecido em lei especial, a flora, a fauna, as belezas naturais, o equilíbrio ecológico e o patrimônio histórico e artístico, bem como evitada a poluição do ar e das águas ${ }^{29}$. (grifos nossos)
\end{abstract}

Cumpre salientar a imprescindibilidade de a citada disposição ser intencionalmente vaga, pois desta forma existe a possibilidade de se amoldar às situações concretas com o passar dos anos, sem que seja imprescindível qualquer alteração legislativa para sua atualização. Assim, verifica-se, por exemplo, que não há dispositivo legal determinando os requisitos a serem atendidos para que sejam cumpridas as finalidades econômicas ou de preservação de fauna e flora.

\footnotetext{
28 CARVALHO, Kildare Gonçalves. Direito Constitucional - Teoria do Estado e da Constituição - Direito Constitucional Positivo. 10. ed. Belo Horizonte: Del Rey, 2004, p. 407.

29 Disponível em: <http://www.planalto.gov.br/ccivil_03/leis/2002/110406.htm> Acesso em: 09 fev. 2015. Art. 1.228.
} 
Importante destacar que existe, entretanto, a proibição expressa aos atos emulativos, quais sejam, aqueles sem proveito qualquer para o seu titular, destinados simplesmente a causar danos ou prejuízos a terceiros ${ }^{30}$.

Assim, com a evolução social, conclui Carvalho (2004, p. 407) que a "propriedade, sem deixar de ser privada, se socializou, com isso significando que deve oferecer à coletividade uma maior utilidade, dentro da concepção de que o social orienta o individual"31.

Desta forma, conclui-se que a função social da propriedade constitui uma obrigação que visa implementar medidas que têm o objetivo de impulsionar a exploração racional do bem, de forma que, concomitantemente, sejam atendidos os anseios econômicos do seu titular, sem desprezar as necessidades coletivas.

\section{APONTAMENTOS SOBRE A PROGRESSIVIDADE EXTRAFICAL}

Os tributos, mormente os impostos, recebem uma classificação quanto a sua função, que pode ser fiscal, extrafiscal ou parafiscal.

Considera-se fiscal quando o tributo tem por finalidade precípua gerar receitas para o ente político. A função extrafiscal destaca-se quando a finalidade maior é intervir no setor privado, o que normalmente ocorre sobre o domínio econômico, incentivando ou desincentivando uma atividade, como acontece, por exemplo, com os impostos de importação, exportação, sobre produtos industrializados e sobre operações de câmbio, crédito e seguro; em segundo plano se encontra a função fiscal. Já o tributo parafiscal é aquele que tem por função, não gerar receitas nem intervir no domínio econômico, mas financiar atividades que não são essenciais ao Estado, mas que são de interesse comum, como acontece com as contribuições de interesse das categorias profissionais ou econômicas, previstas no artigo 149, da CF/88.

Baleeiro (1996, p. 547), conceitua extrafiscalidade como sendo,

aquele tributo que não almeja, prioritariamente, prover o Estado dos meios financeiros adequados a seu custeio, mas antes visa ordenar a propriedade de acordo com sua função social ou intervir em dados conjunturais (injetando ou absorvendo a moeda em circulação) ou estruturais da economia ${ }^{32}$.

\footnotetext{
30 Disponível em: <http://www.planalto.gov.br/ccivil_03/leis/2002/110406.htm> Acesso em: 09 fev. 2015. Art. 1.228, [...] §2 : São defesos os atos que não trazem ao proprietário qualquer comodidade, ou utilidade, e sejam animados pela intenção de prejudicar outrem.

1 CARVAlHO, Kildare Gonçalves. Direito Constitucional - Teoria do Estado e da Constituição - Direito Constitucional Positivo. 10. ed. Belo Horizonte: Del Rey, 2004, p. 407. 
E ainda,

Na tributação extrafiscal progressiva, o proprietário que conduz mal a sua propriedade, conservando-a socialmente inútil, é onerado com encargos fiscais mais elevados, pois mantém comportamento inadequado ao interesse público ou inaptidão para se adaptar a esse interesse (DERZI, in BALEEIRO, 1996, p. 548) ${ }^{33}$.

Neste diapasão, no que tange especificamente ao IPTU, a maioria doutrinária o classificava como um imposto com função fiscal, ou seja, de gerar receitas para os Municípios ou Distrito Federal, entretanto, com o advento da Constituição Federal de 1988 esta classificação se tornou ultrapassada, na medida em que o IPTU passou a ser utilizado também como um instrumento de política urbana, nos termos do artigo $182, \S 4^{\circ}$, inciso II:

\footnotetext{
Art. 182. A política de desenvolvimento urbano, executada pelo Poder Público municipal, conforme diretrizes gerais fixadas em lei, tem por objetivo ordenar o pleno desenvolvimento das funções sociais da cidade e garantir o bem-estar de seus habitantes.

[...]

$\S 4^{\circ}$. É facultado ao Poder Público municipal, mediante lei específica para área incluída no plano diretor, exigir, nos termos da lei federal, do proprietário do solo urbano não edificado, subutilizado ou não utilizado, que promova seu adequado aproveitamento, sob pena, sucessivamente, de:

$[\ldots]$

II - imposto sobre a propriedade predial e territorial urbana progressivo no tempo; $[\ldots]^{34}$.
}

Deste modo, o IPTU deixou de ter função apenas fiscal, de apenas gerar receita para os Municípios, para ter também uma finalidade extrafiscal, de intervenção no setor privado, sobretudo no direito de propriedade, como forma de se incentivar a destinação social da propriedade, dentro da política urbana.

Ademais, salienta-se que existe extrafiscalidade do IPTU também no que tange às alíquotas diferenciadas previstas no artigo $156, \S^{\circ}$, inciso II, da Constituição Federal:

\footnotetext{
33 BALEEIRO, Aliomar. Limitações Constitucionais ao Poder de Tributar. 8. ed. Atualizado por Misabel Abreu Machado Derzi. Rio de Janeiro: Forense, 1996, p. 548.

34 Disponível em: <http://www.planalto.gov.br/ccivil_03/constituicao/constituicaocompilado.htm> Acesso em: 15 jan. 2015.
} 
Art. 156. Compete aos Municípios instituir impostos sobre: [...]

$\S 1^{\circ}$. Sem prejuízo da progressividade no tempo a que se refere o art. $182, \S 4^{\circ}$, II, o imposto previsto no inciso I poderá:

[...]

II - ter alíquotas diferentes de acordo com a localização e o uso do imóvel ${ }^{35}$.

qual,

Corroborando o acima exposto vale a lição de Roque Antônio Carrazza, segundo o

o IPTU pode e deve ser um instrumento de extrafiscalidade. Assim, a alíquota do IPTU pode variar de acordo com o índice de aproveitamento do terreno, com o tipo de construção, com suas dimensões, com sua localização, com o número de pavimentos do imóvel, com sua destinação, e assim avante ${ }^{36}$ (CARRAZZA, 2003, p. 99).

E segue:

Temos, aí, duas situações distintas.

A primeira: o princípio da capacidade contributiva exige que o IPTU tenha alíquotas diferenciadas, conforme os imóveis urbanos sejam mais ou menos valiosos.

A segunda: o inc. II do $\S 1^{\circ}$ do art. 156 da CF exige que o IPTU tenha alíquotas diferentes, de acordo com a localização e o uso do imóvel, ou seja, de acordo com as conveniências locais, expressas no plano diretor do Município.

Nesta última situação não está em jogo o princípio da capacidade contributiva, mas a função social da propriedade ${ }^{37}$ (CARRAZZA, 2003, p. 99).

Daí deflui que o IPTU pode ser extrafiscal quando tem a preocupação de atender à função social da propriedade, faceta esculpida no artigo $182, \S 4^{\circ}$, inciso II, da CF/88. Por outro lado, o IPTU com função eminentemente fiscal também pode ter alíquotas progressivas, tal como está exposto no artigo $156, \S 1^{\circ}$, inciso $\mathrm{I}$, da $\mathrm{CF} / 88$. Cuida-se da progressividade fiscal.

Acerca das progressividades extrafiscal e fiscal convém à lição de Kyoshi Harada:

Nos termos do inciso II, do $\S 4^{\circ}$, do art. 182 da Constituição Federal, o IPTU poderá ser progressivo para regular a função social da propriedade urbana. Nesse tipo de tributação, o fim visado não é o aumento da arrecadação tributária, mas, o desenvolvimento das funções sociais da cidade e garantir o bem-estar social de seus habitantes, tarefa conferida ao Poder Público municipal, nos termos do art. 182 caput da Carta Política ${ }^{38}$ (HARADA, 2002, p. 352-354).

\footnotetext{
35 Disponível em: <http://www.planalto.gov.br/ccivil_03/constituicao/constituicaocompilado.htm> Acesso em: 15 jan. 2015.

36 CARraZZA, Roque Antonio. Curso de Direito Constitucional Tributário. 19. ed. São Paulo: Malheiros Editores, 2003 , p. 99.

37 CARRAZZA, Roque Antonio. Curso de Direito Constitucional Tributário. 19. ed. São Paulo: Malheiros Editores, 2003 , p. 99.

38 HARADA, Kiyoshi. Imposto sobre Propriedade Predial e Territorial Urbana. In: PEIXOTO, Marcelo Magalhães (coord.). IPTU: Aspectos Jurídicos Relevantes. São Paulo: Quartier Latin, 2002, p. 352-354.
} 


\title{
E prossegue,
}

\begin{abstract}
A progressividade fiscal, ou seja, aquela decretada no interesse da arrecadação, levando em conta a capacidade contributiva, tem seu fundamento no $\S 1^{\circ}$, do art. 145 da Constituição Federal, norma de natureza programática que preconiza, sempre que possível, a graduação do imposto segundo a capacidade contributiva. Essa capacidade é aferida objetivamente. Nesse tipo de progressividade, somente o valor venal do imóvel poderá ser tomado como parâmetro para progressão de alíquotas, à medida em que apenas ela espelha, objetivamente, a capacidade econômica do proprietário-contribuinte. A consideração de qualquer outro fator ou elemento retira a natureza fiscal da progressividade $^{39}$ (HARADA, 2002, p. 352-354).
\end{abstract}

Apenas em remate, o IPTU pode se revestir da função meramente fiscal ou, ainda da função extrafiscal, como instrumento de política urbana, visando o atendimento da função social da propriedade.

O artigo 182 da Constituição Federal que trata da política urbana foi regulamentado pela Lei 10.247 de 10 de julho de 2001, conhecida como Estatuto da Cidade, que estabelece normas de ordem pública e interesse social que regulam o uso da propriedade urbana em prol do bem coletivo, da segurança e do bem-estar dos cidadãos, bem como do equilíbrio ambiental ${ }^{40}$.

Os principias objetivos pretendidos pelo Estatuto da Cidade que se correlacionam com a função social da propriedade são o redirecionamento de recursos e riqueza de forma justa, visando combater as desigualdades, a proteção dos direitos humanos evitando a segregação de comunidades carentes e, por fim, a geração de desenvolvimento social de forma sustentável. O Estatuto também traçou os parâmetros do IPTU com alíquotas progressivas no tempo como forma a desestimular o desrespeito a função social da propriedade urbana.

Importante salientar que o Estatuto da Cidade não é uma lei auto-aplicável no que tange ao IPTU, sua executoriedade depender de lei municipal traçando tanto o Plano Diretor (obrigatório para cidades com mais de vinte mil habitantes) como instituindo o IPTU progressivo no tempo, fixando o valor das alíquotas e o período de duração (em anos) em que haverá a progressividade, sempre obedecido o patamar fixado no artigo $7^{\circ 41}$, do citado diploma legal.

\footnotetext{
39 HARADA, Kiyoshi. Imposto sobre Propriedade Predial e Territorial Urbana. In: PEIXOTO, Marcelo Magalhães (coord.). IPTU: Aspectos Jurídicos Relevantes. São Paulo: Quartier Latin, 2002, p. 352-354.

40 Disponível em: <http://www.planalto.gov.br/ccivil_03/leis/leis_2001/110257.htm> Acesso em: 15 jan. 2015.
} 
Para que se alcance a progressividade no tempo do IPTU existem etapas que devem ser atendidas pelo Município, após definição no Plano Diretor de áreas que poderão sofrer esta incidência, bem assim de lei ordinária municipal instituidora do IPTU progressivo no tempo, são elas: a) parcelamento ou edificação compulsória; b) progressividade temporal do IPTU; c) desapropriação sanção. Parcelamento ou edificação compulsória são modalidades em que se exige do titular uma conduta positiva, ou seja, consistem em obrigações de fazer, na qual o Poder Público impõe ao proprietário o dever de lotear ou desmembrar o imóvel, ou ainda, de erigir sob o mesmo uma edificação. Já a desapropriação sanção é o instrumento de intervenção mais gravoso, pois ocorre a expropriação forçada do bem. A indenização não será efetuada de forma prévia nem em dinheiro, mas sim, com títulos da dívida pública, resgatáveis de forma parcelada em até $10(\mathrm{dez})$ anos.

Assim, caso o proprietário do imóvel, mesmo com as imposições feitas pelo Poder Público, resolva não cumprir as determinações permanecendo inerte, haverá implementação do IPTU progressivo no tempo, mediante majoração da alíquota pelo prazo de cinco anos consecutivos, conforme explicam Farias e Rosenvald (2006, p. 217):

a consequência para o inadimplemento da obrigação de edificar ou parcelar no prazo imposto pela lei municipal [...] será a progressividade temporal do Imposto Predial Territorial e Urbano, como excelente medida de desestímulo à propriedade ociosa.

A cada ano de inércia do proprietário o valor do tributo é majorado até que a situação se torne insuportável sem que ele possa alegar, para a determinação, a existência de efeito confiscatório. Isto ocorre porque sua finalidade não é arrecadatória, assim, conforme ensinamentos de Coêlho, (1999, p. 245) "a extrafiscalidade é a utilização dos tributos para

\footnotetext{
41 Disponível em: <http://www.planalto.gov.br/ccivil_03/leis/leis_2001/110257.htm> Acesso em: 15 jan. 2015. Art. $7^{\text {o }}$ Em caso de descumprimento das condições e dos prazos previstos na forma do caput do art. $5^{\mathrm{O}}$ desta Lei, ou não sendo cumpridas as etapas previstas no $\S 5^{\mathrm{O}}$ do art. $5^{\circ}$ desta Lei, o Município procederá à aplicação do imposto sebre a propriedade predial e territorial urbana (IPTU) progressivo no tempo, mediante a majoração da alíquota pelo prazo de cinco anos consecutivos.

$\S 1^{\circ} \mathrm{O}$ valor da alíquota a ser aplicado a cada ano será fixado na lei específica a que se refere o caput do art. $5^{\circ}$ desta Lei e não excederá a duas vezes o valor referente ao ano anterior, respeitada a alíquota máxima de quinze por cento.

$\S 2^{\mathrm{O}}$ Caso-a obrigação de parcelar, edificar ou utilizar não esteja atendida em cinco anos, o Município manterá a cobrança pela alíquota máxima, até que se cumpra a referida obrigação, garantida a prerrogativa prevista no $\operatorname{art.8}{ }^{\mathrm{O}}$.

$\S 3^{\mathrm{O}}$ É vedada a concessão de isenções ou de anistia relativas à tributação progressiva de que trata este artigo.
} 
fins outros que não os da simples arrecadação de meios para o Estado. Nesta hipótese, o tributo é instrumento de politicas econômicas, sociais, culturais etc." ${ }^{, 42}$

Deve ser ressaltado que na progressividade no tempo do IPTU, que tem caráter extrafiscal, não há obediência ao princípio da capacidade contributiva, uma vez que a finalidade não é arrecadatória, mas indutora de um comportamento desejável. Segundo bem esclarece Keziah A. V. Silva PINTO (2012), o IPTU progressivo no tempo tem caráter sancionador e também não se submete ao princípio da vedação ao confisco, podendo, ou melhor, devendo, ter alíquotas suficientemente altas para coibir o comportamento indesejado de não dar a função social à propriedade e estimular o comportamento desejado. Mesmo sem entender ter o IPTU progressivo no tempo caráter sancionador, mas não se submetendo ao princípio da vedação ao confisco, também Sacha Calmon Navarro Coelho, Fernando Dias Menezes de Almeida e Diógines Gasparine apud PINTO (2012, p. 178-181).

A última etapa do procedimento, caso não seja suficiente para o proprietário adequar a propriedade à sua função social, é a desapropriação. Neste caso, se o proprietário não perder o imóvel em razão das alíquotas progressivas no tempo, o perderá em razão de desapropriação.

Conforme se verifica do exposto, a extrafiscalidade é instrumento utilizado pelo direito tributário, não alcançado pela capacidade contributiva, para realização de valores constitucionais fundados na função social da propriedade.

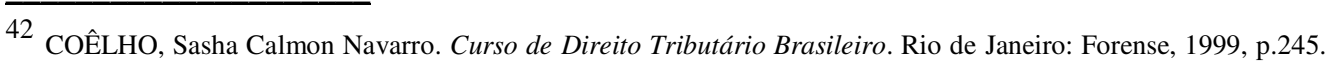




\section{CONCLUSÃO}

A função social da propriedade precisa ser vista pela sociedade, sempre atrelada à ordem econômica e social, como um instrumento tendente a viabilizar a exploração racional do bem e não como um limitador de direitos. Ao mesmo tempo, a visão do direito de propriedade como absoluto, precisa ser transposta.

O IPTU pode se revestir de duas funções: fiscal que é meramente arrecadatória e extrafiscal, que torna referido tributo um eficaz instrumento da Política Urbana, de modo a obrigar que os proprietários deem o adequado aproveitamento ao solo urbano. Neste campo, referido imposto vai apresentar alíquotas progressivas no tempo, ou seja, que aumentam enquanto o proprietário esteja desatendendo ao adequado aproveitamento do solo urbano.

Constitui, na atualidade, tarefa árdua cogitar um imposto que não possua caráter fiscal, entretanto, em um país com grande concentração de terras, muitas improdutivas com finalidade apenas especulativa, a extrafiscalidade é um instrumento a ser mais utilizado para que a concepção social de propriedade insculpida na Constituição Federal seja cumprida com maior eficácia.

Assim, a progressividade extrafiscal do IPTU constitui, na atualidade, um mecanismo a ser utilizado pelos municípios, essencial para o combate às propriedades especulativas que impedem o crescimento e desenvolvimento natural das cidades. 


\section{REFERÊNCIAS}

AMARO, Luciano. Direito Tributário Brasileiro. 14. ed. São Paulo: Saraiva, 2008. BALEEIRO, Aliomar. Limitações Constitucionais ao Poder de Tributar. 8. ed. Atualizado por Misabel Abreu Machado Derzi. Rio de Janeiro: Forense, 1996.

BALEEIRO, Aliomar. Limitações Constitucionais ao Poder de Tributar. 8. ed. Atualizado por Misabel Abreu Machado Derzi. Rio de Janeiro: Forense, 2010.

BARETO, Aires Fernandino. Aplicação do princípio da progressividade. In: $1^{\circ}$ CONGRESSO INTERNACIONAL DE DIREITO TIBUTÁRIA - IBET, 1998, Espírito Santo. Justiça Tributária. Vitória: Instituto Brasileiro de Estudos Tributários, 1998. p. 37 - 50.

BRASIL. Supremo Tribunal Federal. Súmula n.668. É inconstitucional a lei municipal que tenha estabelecido, antes da Emenda Constitucional 29/2000, alíquotas progressivas para o IPTU, salvo se destina a assegurar o cumprimento da função social da propriedade urbana. Disponível em: $<\mathrm{http} / / / \mathrm{www}$. stf.jus.br/portal/cms/verTexto.asp?servico=jurisprudenciaSumula\&pagina=sumu la_601_700> Acesso em: 09 fev. 2015.

BRASIL. Constituição (1988). Emenda constitucional n. 29, de 13 de setembro de 2000. Altera os arts. 34, 35, 156, 160, 167 e 198 da Constituição Federal e acrescenta artigo ao Ato das Disposições Constitucionais Transitórias, para assegurar os recursos mínimos para o financiamento das ações e serviços públicos de saúde. Diário Oficial da União, Brasília, 14 set. 2000. Disponível em: < http://www.planalto.gov.br/ccivil_03/constituicao/Emendas/Emc/emc29.htm> Acesso em 09 fev. 2015.

BRASIL. Constituição (1824) Constituição Política do Império do Brazil. Rio de Janeiro, 22 abr. 1824. Disponível em: <http://www.planalto.gov.br/ccivil_03/Constituicao/Constituicao24.htm>. Acesso em: 15 jan. 2015.

BRASIL. Constituição (1988) Constituição da República Federativa do Brasil. Brasília, 05 out. 1988. Disponível em: < http://www.planalto.gov.br/ccivil_03/constituicao/constituicao.htm>. Acesso em: 15 jan.2015.

BRASIL. Lei n. 3.071, de 01 de janeiro 1916. Código Civil dos Estados Unidos do Brasil.

Diário Oficial da União, Brasília, 01 jan. 1916. Disponível em: <http://www.planalto.gov.br/ccivil_03/leis/L3071.htm> Acesso em: 09 fev. 2015.

BRASIL. Lei n. 5.172, de 25 de outubro de 1966. Dispõe sobre o Sistema Tributário Nacional e institui normas gerais de direito tributário aplicáveis à União, Estados e Municípios. Diário Oficial da União, Brasília, 31 out. 1966. Disponível em: < http://www.planalto.gov.br/ccivil_03/leis/15172.htm> Acesso em: 09 fev. 2015.

BRASIL. Lei n. 10.257, de 10 de julho de 2001. Regulamenta os arts. 182 e 183 da Constituição Federal, estabelece diretrizes gerais da política urbana e dá outras providências. Diário Oficial da União, Brasília, 17 jul. 2001. Disponível em: <http://www.planalto.gov.br/ccivil_03/leis/leis_2001/110257.htm > Acesso em: 15 jan. 2015. 
BRASIL. Lei n. 10.406, de 10 de janeiro de 2002. Institui o Código Civil. Diário Oficial da União, Brasília, 11 jan. 2002. Disponível em: <http://www.planalto.gov.br/ccivil_03/leis/2002/110406.htm> Acesso em: 09 fev. 2015.

BITTAR FILHO, Carlos Alberto. A apropriação do solo no Brasil colonial e monárquico: uma perspectiva histórico-jurídica. Revista de informação legislativa: v. 37, n. 148. out./dez. 2000, p. 148.

CAMARGOS, Luciano Dias Bicalho. O Imposto Territorial Rural e a função social da propriedade - Doutrina, Prática e Jurisprudência. Belo Horizonte: Del Rey, 2001.

CARRAZZA, Elizabeth Nazar. IPTU e progressividade - igualdade e capacidade contributiva. Curitiba: Juruá, 1992.

CARRAZZA, Roque Antonio. Curso de Direito Constitucional Tributário. 19. ed. São Paulo: Malheiros Editores, 2003.

CARRAZZA, Roque Antonio. Curso de Direito Constitucional Tributário. 27. ed. São Paulo: Malheiros Editores, 2010.

CARVALHO, Paulo de Barros. Curso de Direito Tributário. 17. ed. São Paulo: Saraiva, 2005.

CARVALHO, Kildare Gonçalves. Direito Constitucional - Teoria do Estado e da Constituição Direito Constitucional Positivo. 10. ed. Belo Horizonte: Del Rey, 2004.

COÊLHO, Sacha Calmon Navarro. Curso de Direito Tributário Brasileiro. 11. ed. Rio de Janeiro: Forense, 2010.

COÊLHO, Sasha Calmon Navarro. Curso de Direito Tributário Brasileiro. Rio de Janeiro: Forense, 1999.

COÊLHO, Sacha Calmon Navarro; DERZI, Misabel Abreu Machado. Do Imposto sobre a Propriedade Predial e Territorial Urbana. São Paulo: Saraiva, 1982.

DINIZ, Maria Helena. Curso de Direito Civil Brasileiro: Direito das Coisas. 17ed. São Paulo: Saraiva, 2002.

FARIAS, Cristiano Chaves de; ROSENVALD, Nelson. Direitos Reais. 2. ed. Rio de Janeiro: Lúmen Juris Editora, 2006.

GOUVÊA, Marcus de Freitas. A Extrafiscalidade no Direito Tributário. Belo Horizonte: Del Rey, 2006.

HARADA, Kiyoshi. Imposto sobre Propriedade Predial e Territorial Urbana. In: PEIXOTO, Marcelo Magalhães (coord.). IPTU: Aspectos Jurídicos Relevantes. São Paulo: Quartier Latin, 2002.

MACHADO, Hugo de Brito. Curso de Direito Tributário. 27. ed. rev. atual. e ampl. São Paulo: Malheiros Editores, 2006. 
PEIXOTO, Marcelo Magalhães (coord.). IPTU: Aspectos Jurídicos Relevantes. São Paulo: Quartier Latin, 2002.

PELUSO, Cesar (Coord.). Código Civil Comentado. 8. ed. rev. e ampl. São Paulo: Manole, 2014.

PINTO, Keziah Alessandra Vianna Silva. IPTU. Política urbana e aspectos constitucionais. Campinas: Alínea, 2012.

SABBAG, Eduardo. Manual de Direito Tributário. 3. ed. São Paulo: Saraiva, 2011. SILVA, José Afonso da. Direito Urbanístico Brasileiro. 3.ed. São Paulo: Malheiros, 2000. 